\title{
Effects of Pilayella littoralis on Fucus vesiculosus recruitment: implications for community composition
}

\author{
Sonja Råberg ${ }^{1, *}$, Rita Berger-Jönsson ${ }^{2}$, Anna Björn ${ }^{1}$, Edna Granéli ${ }^{2}$, Lena Kautsky ${ }^{1}$ \\ ${ }^{1}$ Department of Botany, University of Stockholm, 10691 Stockholm, Sweden \\ ${ }^{2}$ Department of Biology and Environmental Science, University of Kalmar, 39129 Kalmar, Sweden
}

\begin{abstract}
With increasing eutrophication in coastal areas, mass developments of annual filamentous algae, such as Pilayella littoralis and Enteromorpha spp., have increased. Simultaneously, the perennial macroalga Fucus vesiculosus has declined in many areas in the Baltic Sea. To test the effects of $P$. littoralis on $F$. vesiculosus we performed a number of laboratory and field studies. The most severe negative effect observed was the reduced number of settled germlings (95\%) when P. littoralis was present on the substrate prior to seeding of $F$. vesiculosus eggs. A low concentration $(0.1 \%)$ of exudates from $P$. littoralis reduced the attachment rate of $F$. vesiculosus during the initial $12 \mathrm{~h}$, while higher concentrations of exudates (5 to $10 \%$ ) negatively affected germination and rhizoid development. These results could explain for the negative correlations that have been observed between $F$. vesiculosus and annual filamentous algae in the Baltic Sea. Our field data showed that the biomass of filamentous algae was higher in the summer than in the autumn, suggesting that recruits from the summer-reproducing $F$. vesiculosus may encounter more competition from $P$. littoralis and other filamentous algae than do recruits from the autumn-reproducing populations. The summerand autumn-reproducing $F$. vesiculosus host similar abundance and biomass of their associated flora and fauna; hence, a potential shift from summer- to autumn-reproducing $F$. vesiculosus would not change the overall community composition in this ecosystem.
\end{abstract}

KEY WORDS: Summer-reproducing Fucus vesiculosus - Autumn-reproducing Fucus vesiculosus • Pilayella littoralis . Post-settlement survival · Community composition · Filamentous algae · Attachment $\cdot$ Interference competition $\cdot$ Allelopathy

\section{INTRODUCTION}

Over the past few decades, mass developments of annual filamentous algae, such as Enteromorpha spp., Pilayella littoralis and Cladophora spp., have increased in coastal areas around the world (Rosenberg et al. 1996, Schramm \& Nienhuis 1996, Johansson et al. 1998, Eriksson et al. 2002), including the Baltic Sea (Hällfors et al. 1984, Cederwall \& Elmgren 1990, Eriksson et al. 1998, Rönnberg \& Mathiesen 1998, Lotze et al. 1999, Vahteri et al. 2000). At the same time, the distribution of the perennial macroalga Fucus vesiculosus has become more restricted (Kangas et al. 1982, Kautsky et al. 1986, Eriksson et al. 1998, Schramm 1999, Middelboe \&
Sand-Jensen 2000), except for some local recovery in recent years (Kautsky 2000, Nilsson et al. 2004).

Fucus vesiculosus (hereafter Fucus) is the only large brown alga in the northern Baltic proper, where it provides one of the most species-rich habitats, offering protection, food supply and spawning area to many different groups of fauna (Haage 1975, Wallentinus 1979). The diversity and abundance of associated fauna in these communities is high, as shown in a study by Haage (1975). Due to the high biodiversity of the Fucus community and its ecological significance in the Baltic Sea (Kautsky et al. 1992), it is important to understand the various factors that structure this community and its biodiversity. 
Laboratory and field-based studies have shown that a great number of complex factors and interactions may underlie the overall decline of Fucus populations in the Baltic Sea (Kangas et al. 1982, Vogt \& Schramm 1991, Berger et al. 2004). In addition, processes involving egg settlement and survival of recruits may represent a bottleneck for fucoid algae (Vadas et al. 1992, Serrão 1996). Further, negative correlations between percentage cover of filamentous or foliose species and large perennial fucoid species have been observed (Worm \& Chapman 1996, Worm et al. 1999), suggesting interspecific interactions between these 2 different forms of algae. The mechanism underlying the negative correlations is not always clear; however, space occupation by filamentous algae has been shown to have a strong negative effect on the settling success of Fucus (Worm et al. 2001, Berger et al. 2003).

Pilayella littoralis (hereafter Pilayella) is a common fast-growing epilithic and epiphytic brown alga that occurs in the upper littoral zone in the Baltic Sea, cooccurring with Fucus. It dominates during spring and early summer (Wallentinus 1979, Kiirikki \& Lehvo 1997, Lotze et al. 1999) and starts to detach and decay in mid-summer (Aneer 1987). In a laboratory study, Aneer (1987) found that some filamentous algae, including Pilayella, had negative effects on fish egg survival, and suggested that the high natural mortality of Baltic herring Clupea harengus may be locally correlated to the toxic exudates of brown filamentous algae. Decomposition of filamentous algae locally generates high levels of nutrients (Vahteri et al. 2000) such as nitrate, phosphate and ammonium, which can all have damaging effects on the early life stages of macroalgae (Kevekordes 2001, Bergström et al. 2003). Thus, high abundance of detaching Pilayella during Fucus reproduction may have negative consequences for the recruitment of Fucus. Besides nutrients, exudates from Pilayella may also contain chemicals or secondary metabolites that can be harmful to Fucus recruits (McInnes et al. 1984).

Fucus reproduction peaks in 2 different periods in the Baltic Sea: May-June and September-October. These different patterns of reproduction are believed to be expressions of different genotypes of Fucus (Berger et al. 2001). Genetic analysis of Fucus aiming to cast light on these 2 different reproduction patterns is still in progress, and it is as yet unclear whether there are 2 distinct genotypes. We will therefore refrain from using the word 'genotype' in this article. Since the biomass of Pilayella peaks in spring, it is possible that fucoid populations that reproduce in autumn encounter less competition from this filamentous alga, and hence have an advantage over fucoid populations that reproduce during the Pilayella outbreak.
This study primarily aimed to test whether Pilayella has negative effects on Fucus settlement and recruitment (i.e. attachment, germination, rhizoid development and survival). To evaluate potential effects in situ, the biomass of Pilayella and total filamentous algae, as well as the biomass of Fucus juveniles, was measured in the field during the 2 periods of Fucus reproduction. Possible ecological consequences of a shift from summer- to autumn-reproducing Fucus were also investigated by sampling associated flora and fauna from individuals representing the 2 different reproductive patterns. Seven hypotheses (H-1 to H-7) were addressed, and to answer these hypotheses we conducted both laboratory and field studies.

\section{MATERIALS AND METHODS}

Preparation of Pilayella exudates. Fresh Pilayella was collected at the Askö Laboratory, Sweden $\left(58^{\circ} 49^{\prime} \mathrm{N}, 19^{\circ} 39^{\prime} \mathrm{E}\right)$, in May 2000, and sub-samples were placed in aquaria filled with seawater of the same salinity and temperature as the water in the sampling area $\left(6.5 \%\right.$ salinity, $\left.13 \pm 1^{\circ} \mathrm{C}\right)$. To test the hypothesis that exudates from decaying Pilayella have stronger negative effects on Fucus recruitment than do fresh Pilayella (H-1), samples were placed either in the light and aerated (FP, fresh Pilayella) or in the dark and not aerated (DP, decaying Pilayella) (approximately $0.5 \mathrm{~g}$ dry weight $1^{-1}$ water). The latter treatment was conducted to prompt Pilayella decay, a phenomenon which naturally occurs in summer after Pilayella detachment. Material was left under these conditions for $3 \mathrm{~d}$ before the exudate was filtered off. Half of the Pilayella exudate was directly used in the germination, survival and rhizoid-development experiment, while the other half was frozen for later use in the attachment experiment. Since nutrients are known to have negative effects on the attachment and recruitment of macroalgae (Kevekordes 2001, Bergström et al. 2003), we analysed the nitrate, ammonium and phosphate content of the exudates, according to methods described by Valderrama (1995).

Effects of exudates on Fucus attachment. To test whether initial attachment of fertilized Fucus eggs is prevented by exudates of Pilayella (H-2), a laboratory experiment was carried out in October 2002. Pilayella exudates (FP and DP) were diluted to 0.1, 1, 5, 10 and $25 \%$ of the original solution, and $8 \mathrm{ml}$ of each concentration (and of the seawater control) was placed in acid-washed petri dishes (10 ml total volume) (total $\mathrm{n}=$ 60 FP, 60 DP and 12 control). Ripe Fucus (>50 individuals) was collected $2 \mathrm{~d}$ before the experiment at 2 locations $100 \mathrm{~km}$ apart. Egg release and fertilization were induced according to methods described in Bergström 
et al. (2003); $2 \mathrm{ml}$ of egg suspension (ca. 150 to 200 eggs) was added to the petri dishes, which were then immediately transferred to a room held at a constant temperature of $13 \pm 1^{\circ} \mathrm{C}$ with a $12: 12 \mathrm{~h}$, light:dark cycle which mimicked natural conditions where the samples had been collected. Three replicates were removed from each treatment at 6, 12, 24 and $48 \mathrm{~h}$ after fertilization to estimate the attachment success. Each removed dish was carefully agitated and the treatment medium containing non-attached zygotes was poured into an empty glass tube. Both the attached and nonattached zygotes were preserved with Lugol's solution. The number of zygotes was counted under a stereo microscope and the percentage of attached zygotes was calculated.

Germination, survival and rhizoid development. The hypothesis that Pilayella exudates negatively affect germination, survival and rhizoid development (H-3) was tested in May 2000. Ripe receptacles of Fucus were collected in the Askö area and brought to the laboratory, where they were stored damp and in the dark in plastic bags at $4^{\circ} \mathrm{C}$, after sex was determined and the males and females separated. When gamete release was expected, female and male receptacles were placed separately in the same concentrations of Pilayella exudates as were used in the attachment experiment (control, 0.1, 1, 5, 10 and 25\%) at $13 \pm$ $1^{\circ} \mathrm{C}$. Eggs and sperm from treatments with the same concentration of exudates were then mixed and left for fertilization for $1 \mathrm{~h}$. Fertilization success was determined using a solution of $0.0001 \%$ Calcofluor White (see Serrão et al. 1996). After fertilization, $5 \mathrm{ml}$ of the suspension of fertilized eggs was transferred to petri dishes pre-filled with $5 \mathrm{ml}$ of the various treatment media ( $\mathrm{n}=5$ dishes per treatment). The number of zygotes in each petri dish was counted after $24 \mathrm{~h}$, the germination frequency was checked after $5 \mathrm{~d}$ and the survival and number of germlings producing rhizoids was checked after $12 \mathrm{~d}$. The percentage of surviving germlings was calculated as the difference between Days 12 and 5.

Substrate competition. To test whether Pilayella physically prevents establishment of Fucus germlings (H-4), small stones (5 to $10 \mathrm{~cm}^{2}$ ) with attached Pilayella ( $\mathrm{n}=10)$ were collected in the Askö area in June 2001. To standardize the coverage of Pilayella, the turfs were cut to uniform height (ca. $3 \mathrm{~cm}$ ), representing a biomass of approximately 0.2 to $0.3 \mathrm{~g}$ dry wt $\mathrm{cm}^{-2}$. The stones were also washed to exclude fine sediments trapped in the turfs. Stones from the same area without Pilayella were used as controls $(n=10)$. Fertilized eggs were seeded onto the stones, which were then stored in an outdoor tank for 3 mo before the surviving germlings were counted. On each stone, the germlings present on a randomly chosen area of $3.1 \mathrm{~cm}^{2}$ were counted under a stereomicroscope. The germlings were recalculated to number of germlings $\mathrm{dm}^{-2}$ substrate.

Occurrence of filamentous algae, Fucus juveniles and macrofauna in the field. To investigate the hypothesis that zygotes from the autumn-reproducing Fucus encounter less competition with filamentous algae than do zygotes from the summer-reproducing populations (H-5), the occurrence of Pilayella and other filamentous algae was quantified during the 2 different periods of Fucus reproduction (May and September) in 2001. The biomass of 1 to 2 yr old Fucus juveniles under the canopy of summer- and autumnreproducing Fucus was also sampled to investigate the hypothesis that the autumn-reproducing Fucus achieve greater recruitment success than do the summer-reproducing Fucus (H-6). Samples of both summer- and autumn-reproducing Fucus were collected to examine further the null hypothesis that Fucus is inhabited by similar abundance and biomass of associated macrofauna and epiphytic filamentous algal, irrespective of reproduction pattern (H-7). Individuals from 5 summer- and autumn-reproducing Fucus stands were collected randomly with net bags $(1 \mathrm{~mm}$ mesh size) at different sites in the Askö area ( $\mathrm{n}=3$ for both summer- and autumn-reproducing Fucus collected in May, and n = 3 for autumn- and n = 4 for summer-reproducing Fucus collected in September) at approximately 0.3 to $0.5 \mathrm{~m}$ depth. Razor blades were used to clear the Fucus of epiphytic filamentous algae from which macrofauna were separated and counted. The area under the collected Fucus stand was sampled using a square frame $(0.25 \times 0.25 \mathrm{~m})$, with an attached net bag ( $1 \mathrm{~mm}$ mesh size); a scraper was used to clear the vegetation. The epilithic filamentous algae and 1 to 2 yr old Fucus juveniles sampled inside the frame were separated out for weighing. The macrofauna, filamentous algae, Fucus individuals and juveniles were dried to constant dry weight at $50^{\circ} \mathrm{C}$. The biomass of epiphytic filamentous algae and the abundance and biomass of associated fauna were recalculated as $100 \mathrm{~g}$ dry wt Fucus, and the epilithic algae and Fucus juveniles were transformed to $\mathrm{g}$ dry wt $\mathrm{m}^{-2}$.

Statistical analyses. Statistical analyses were performed using SPSS 9.0.1 for Windows and Statistica 6.1. Homogeneity of variance was tested with Cochran's test, and normality of residuals with the KolmogorovSmirnov $(\mathrm{N}>50)$ and Shapiro-Wilk $(\mathrm{N}<50)$ tests. A general linear model (GLM) was used in the attachment experiment to evaluate the effects of treatment (FP and DP), concentration and time on attachment, and Tukey post-hoc testing was used for a posteriori comparisons. Due to the heterogeneity of the variances, a Mann-Whitney $U$-test was used to determine whether the percentages of germination, survival and rhizoid development differed between treatment 
Table 1. Nutrient concentrations $\left(\mu \mathrm{mol} \mathrm{l}^{-1}\right)$ in the various solutions of Pilayella littoralis exudates. Values in bold numbers indicate very high concentrations, according to the Swedish EPA assessment of water quality (Naturvårdsverket 1999)

\begin{tabular}{|c|c|c|c|c|c|c|}
\hline \multirow{2}{*}{$\begin{array}{l}\text { Exudate } \\
\text { conc. }(\%)\end{array}$} & \multicolumn{3}{|c|}{ Fresh } & \multicolumn{3}{|c|}{ Decaying } \\
\hline & $\mathrm{NO}_{3}-\mathrm{N}$ & $\mathrm{NH}_{4}-\mathrm{N}$ & $\mathrm{PO}_{4}-\mathrm{P}$ & $\mathrm{NO}_{3}-\mathrm{N}$ & $\mathrm{NH}_{4}-\mathrm{N}$ & $\mathrm{PO}_{4}-\mathrm{P}$ \\
\hline 0.1 & $<0.001$ & $<0.001$ & $<0.001$ & $<0.001$ & 0.02 & 0.05 \\
\hline 1 & $<0.001$ & $<0.001$ & $<0.001$ & 0.02 & 0.2 & 0.5 \\
\hline 5 & 0.02 & 0.03 & $<0.001$ & 0.09 & 0.9 & 2.5 \\
\hline 10 & 0.03 & 0.06 & $<0.001$ & 0.2 & 1.9 & 5.0 \\
\hline 25 & 0.08 & 0.15 & 0.03 & 0.4 & 4.7 & 12.6 \\
\hline
\end{tabular}

media (FP and DP). A 1-way ANOVA with a post-hoc test that does not assume equal variances (Dunnett T3 test) was thereafter used to test for differences between concentrations. Data pertaining to the abundance of established germlings on stones were transformed $(\log (x+100))$ to meet the assumptions of homogeneity of variance, and a 1-way ANOVA was used to test for differences between stones with and without Pilayella.

Data from the field study (epiphytic and epilithic Pilayella and total filamentous algae, Fucus juveniles under the canopy and biomass and abundance of associated fauna) were analysed using a 2-way ANOVA with 'season' and 'Fucus period of reproduction' as fixed factors. The data pertaining to epiphytic and epilithic Pilayella were transformed $(\operatorname{Arctan}(x+100))$, as were the data pertaining to total epilithic filamentous algae, Fucus juveniles and abundance of Radix balthica (formerly Lymnaea peregra) $\left(\log _{10}(x+1)\right)$, so as to meet the assumptions of homogeneity of variance.

\section{RESULTS}

\section{Nutrient analysis of Pilayella exudates}

Nutrient concentrations (in $\mu \mathrm{mol} \mathrm{l}^{-1}$ ) in the original exudates from fresh and decaying Pilayella were 0.3 and $1.7 \mathrm{NO}_{3}-\mathrm{N}, 0.6$ and $18.9 \mathrm{NH}_{4}-\mathrm{N}$ and 0.1 and $50.5 \mathrm{PO}_{4}-\mathrm{P}$, respectively. The proportions of nutrients in the different concentrations of exudates are shown in Table 1.

\section{Effects of exudates on Fucus attachment}

Attachment of Fucus was initially inhibited (6 to $12 \mathrm{~h})$ by exudates from both fresh and decaying Pilayella (Fig. 1). Approximately $20 \%$ of the fertilized eggs attached in the 5 different concentrations $(0.1$, $1.0,5,10$ and $25 \%$ ) of both exudates (FP and DP) at 6 and $12 \mathrm{~h}$ after fertilization, while about $80 \%$ managed to attach in the controls (Tukey posthoc, $\mathrm{p}<0.05$ in all cases). At 24 and 48 $\mathrm{h}$ after fertilization neither exudate $(\mathrm{p}>$ 0.05 in both cases) produced negative effects, and at $48 \mathrm{~h}, 80$ to $98 \%$ of all zygotes had attached irrespective of treatment.

\section{Germination, survival and rhizoid development}

The effect of exudates on germination, rhizoid development and survival of Fucus germlings did not differ between the 2 treatment media (FP and DP) (Mann-Whitney $\mathrm{p}>0.05$, in all cases). The lowest tested concentration $(0.1 \%)$ of fresh Pilayella exudate had a positive effect on germination ( $\mathrm{p}<0.05)$, while a high concentration $(25 \%)$ of both FP and DP exudates affected germination negatively (Dunnett T3 post-hoc $\mathrm{p}<0.01$ and $\mathrm{p}<0.05$, respectively) (Fig. 2A). The rhizoid development process was more sensitive to the treatments, and was

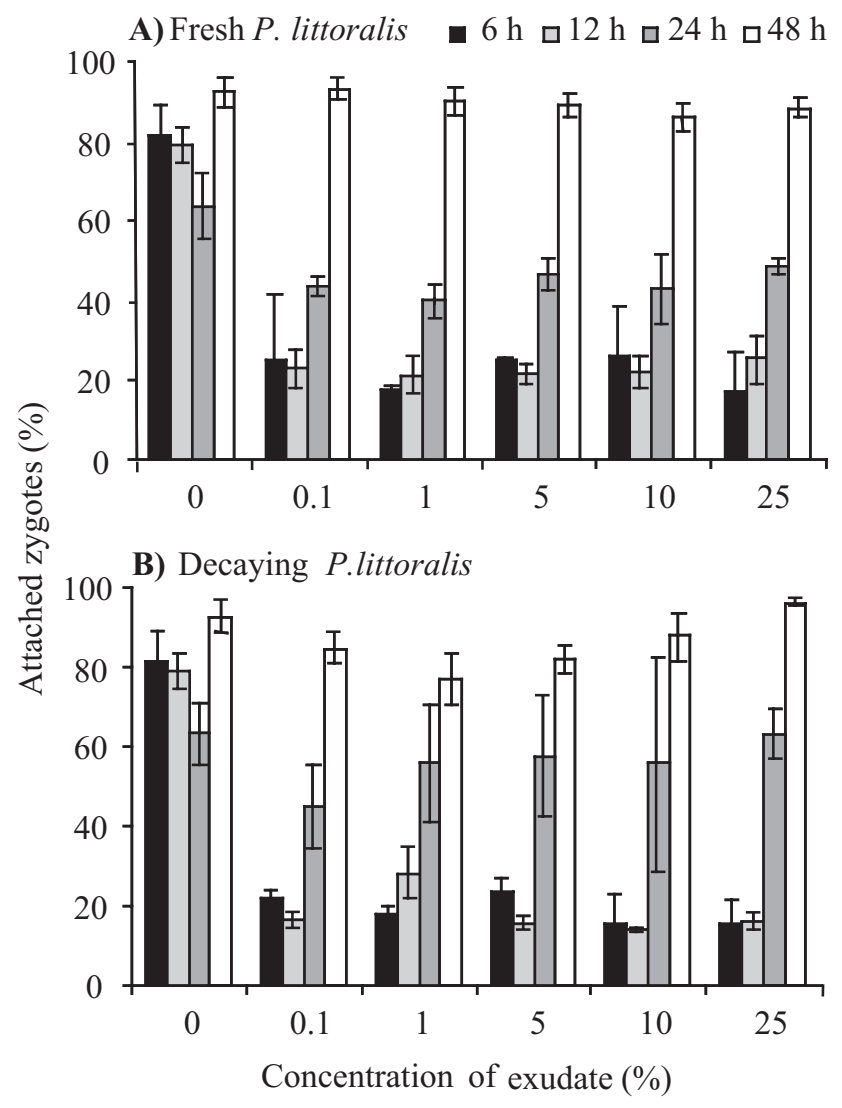

Fig. 1. Fucus vesiculosus. Attachment (\%) of germlings at 6 , 12, 24 and $48 \mathrm{~h}$ in exudates from (A) fresh and (B) decaying Pilayella littoralis. Bars show mean value $\pm \mathrm{SE}$ 
already reduced in $1 \%$ of DP $(p<0.01)$ and $5 \%$ of FP $(p<0.05)$ exudates (Fig. 2B). Similar concentrations had a positive effect on the survival of the germlings (12 d), where FP exudates enhanced survival at 1 and $10 \%$ ( $<<0.01$ and $<0.05$, respectively) while DP exudates had a positive significant effect at concentrations of 10 and $25 \%(\mathrm{p}<0.001$ and $<0.01$, respectively) (Fig. 2C). The survival rate in the controls was, however, rather low at approximately $25 \%$ (Fig. 2 C).

\section{Substrate competition}

Fewer Fucus germlings became established on substrates on which Pilayella was present prior to settling. Fewer than 5 germlings $\mathrm{dm}^{-2}$ became established on stones with turfs, while about 100 germlings $\mathrm{dm}^{-2}$ became established on stones free from epilithic Pilayella ( $\mathrm{p}<0.001)$, representing a $95 \%$ reduction in settled germlings.

\section{Occurrence of Pilayella and total filamentous algae}

The biomass of Pilayella as epiphytes on Fucus and the total biomass of epiphytic filamentous algae differed significantly ( $p<0.001$ and $<0.05$, respectively) between the 2 collection periods (May and September), the highest biomass being found in May, while no difference was detected between summer- and autumn-reproducing Fucus (Table 2, Fig. 3A). The dominant epiphytic filamentous alga in May was Pilayella, while the brown alga Dictyosiphon foeniculaceus contributed the highest epiphytic biomass in September.

The same relationship in biomass variation between May and September was found for the epilithic filamentous algae, with a significantly higher biomass of Pilayella and total filamentous algae occurring in May ( $p<0.01$ in both cases) than in September, with no difference between summer- or autumn-reproducing Fucus (Table 2). The biomass of epilithic Pilayella was approximately 34.5 and $3.3 \mathrm{~g}$ dry $\mathrm{wt} \mathrm{m}^{-2}$ in May and September, respectively, while the biomass of total epilithic filamentous algae was slightly higher, at 35.4

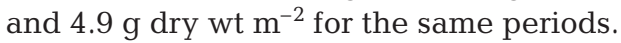

\section{Juveniles under the canopy of Fucus}

There were no significant $(\mathrm{p}>0.05)$ differences between season (i.e. May and September) or between summer- and autumn-reproducing Fucus in terms of biomass of 1 to $2 \mathrm{yr}$ old juveniles collected under the Fucus canopy (Table 2, Fig. 3B).

\section{Associated macrofauna in Fucus}

The 5 most common macrofaunal species living in Fucus were the crustaceans Gammarus spp. and Idotea baltica, the gastropods Theodoxus fluviatilis and Radix balthica and the bivalve Mytilus edulis. The abundance of these species and the total number of collected fauna did not differ between summer- and autumn-reproducing Fucus stands ( $p>0.05$ ) (Fig. 3C). The only species that differed significantly in abundance $(p<0.01)$ between sampling times was Gammarus spp., with the highest numbers occurring in May (no data shown).

The biomass of associated fauna followed the same pattern as did the abundance data, and did not differ significantly between summer- and autumn-reproduc-
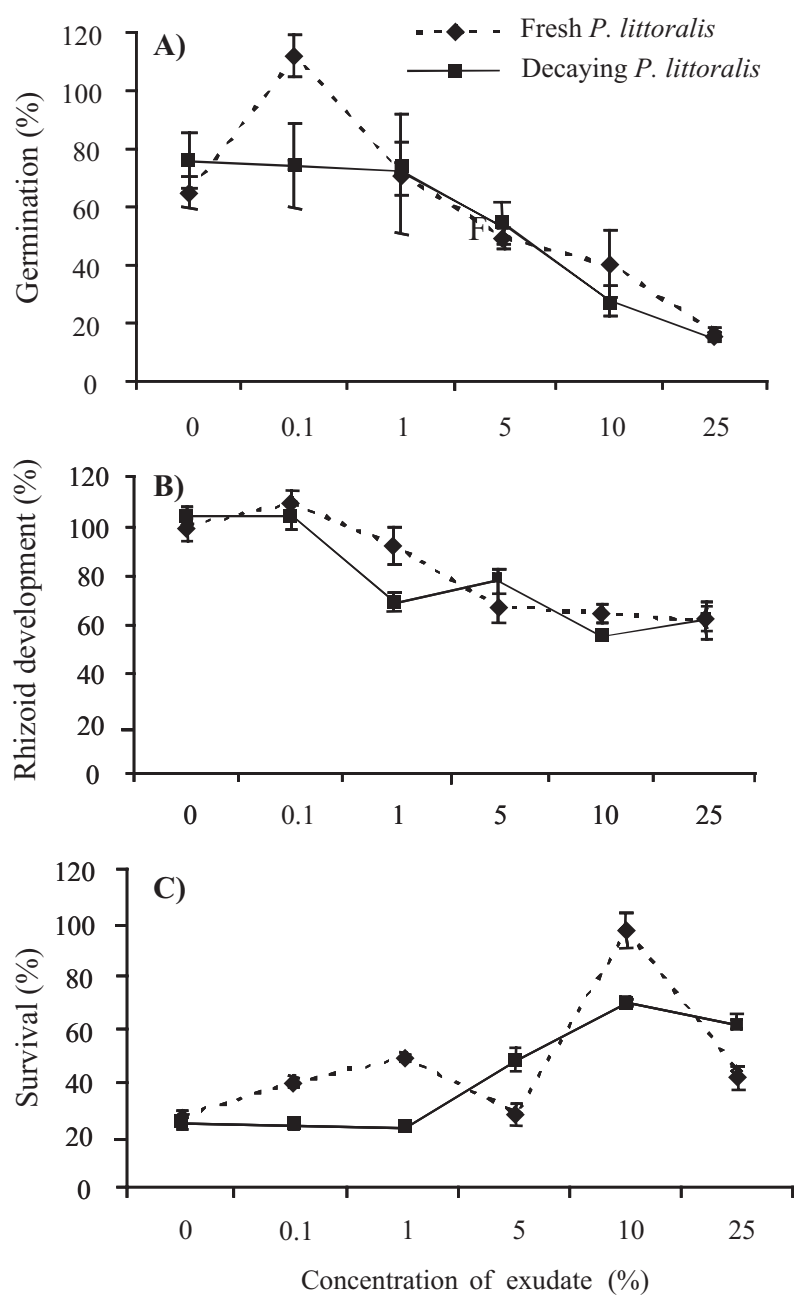

Fig. 2. Fucus vesiculosus. (A) Germination frequency at $5 \mathrm{~d}$ after fertilization, (B) rhizoid development at $12 \mathrm{~d}$ after fertilization and (C) survival frequency at $12 \mathrm{~d}$ after fertilization of germlings in treatment media with fresh and decaying Pilayella littoralis (mean $\pm \mathrm{SE}$ ) 
Table 2. Results of the 2-way ANOVAs testing for differences in the biomass of epiphytic and epilithic Pilayella littoralis and total filamentous algae as well as Fucus vesiculosus juveniles between different collection times, i.e. season (May and September), and different periods of $F$. vesiculosus reproduction (i.e. summer- and autumn-reproducing $F$. vesiculosus). $\mathrm{ns}=\mathrm{p}>0.05$

\begin{tabular}{|c|c|c|c|c|}
\hline Source of variation & $\mathrm{df}$ & MS & $F$ & $\mathrm{p}$ \\
\hline \multicolumn{5}{|c|}{ Biomass of epiphytic $P$. littoralis $100 \mathrm{~g} \mathrm{~g}^{-1}$ dry wt $F$. vesiculosus } \\
\hline Season & 1 & 0.000 & 30.19 & $<0.001$ \\
\hline Period of reproduction & 1 & 0.000 & 0.22 & ns \\
\hline Season $\times$ period of reproduction & 1 & 0.000 & 0.52 & ns \\
\hline Residual & 8 & 0.000 & & \\
\hline \multicolumn{5}{|c|}{ Biomass of total epiphytic filamentous algae $100 \mathrm{~g}^{-1}$ dry wt $F$. vesiculosu. } \\
\hline Season & 1 & 1205.3 & 11.00 & $<0.05$ \\
\hline Period of reproduction & 1 & 2.7 & 0.02 & ns \\
\hline Season $\times$ period of reproduction & 1 & 74.1 & 0.68 & ns \\
\hline Residual & 8 & 109.6 & & \\
\hline \multicolumn{5}{|l|}{ Biomass of epilithic $P$. littoralis $\mathrm{m}^{-2}$} \\
\hline Season & 1 & 0.000 & 21.24 & $<0.01$ \\
\hline Period of reproduction & 1 & 0.000 & 0.15 & ns \\
\hline Season $\times$ period of reproduction & 1 & 0.000 & 0.27 & ns \\
\hline Residual & 9 & 0.000 & & \\
\hline \multicolumn{5}{|c|}{ Biomass of total epilithic filamentous algae $\mathrm{m}^{-2}$} \\
\hline Season & 1 & 2.496 & 18.22 & $<0.01$ \\
\hline Period of reproduction & 1 & 0.000 & 0.00 & ns \\
\hline Season $\times$ period of reproduction & 1 & 0.013 & 0.09 & ns \\
\hline Residual & 9 & 0.137 & & \\
\hline \multicolumn{5}{|l|}{ Biomass of Fucus juveniles $\mathrm{m}^{-2}$} \\
\hline Season & 1 & 0.348 & 3.39 & ns \\
\hline Period of reproduction & 1 & 0.321 & 3.13 & ns \\
\hline Season $\times$ period of reproduction & 1 & 0.345 & 3.36 & ns \\
\hline Residual & 9 & 0.103 & & \\
\hline
\end{tabular}

ing Fucus ( $\mathrm{p}>0.05$ ) (no data shown). The only faunal species of which the biomass differed significantly between the collection seasons was again Gammarus spp., with the highest biomass occurring in May $(\mathrm{p}<$ 0.05) (no data shown).

\section{DISCUSSION}

\section{Effects of Pilayella exudates}

This report demonstrates that the negative impacts of Pilayella exudates on Fucus may inhibit Fucus recruitment in areas with great abundance of Pilayella. The results further show that the toxic products in Pilayella may not, as hypothesised, be released mainly by decomposing Pilayella (H-1), but also from viable populations.

The hypothesis that the initial attachment process of Fucus zygotes would be sensitive to exudates of Pilayella (H-2) was, however, supported. Zygotes were most sensitive to the exudates at 6 and $12 \mathrm{~h}$ after fertilization, and initial attachment was reduced even at the lowest concentration tested. The later life stages, i.e. germination
(5 d) and rhizoid development (12 d), were also negatively affected by Pilayella exudates, but only at higher concentrations. The survival of zygotes (12 d) was in fact positively affected by approximately the same high concentrations; thus our hypothesis (H-3) could only partly be supported. These results suggest that Fucus sensitivity to potentially toxic substances was related to its life stage.

After fertilization, Fucus embryos must undergo a series of critical developmental steps, including axis fixation, cell wall deposition, secretion of adhesive products, germination of rhizoid and cell division (Kropf 1997, Brownlee \& Bouget 1998). Our results indicate that Pilayella exudates may contain substances that retard or inhibit these processes. Inhibited attachment in the littoral zone may involve an increased risk that Fucus may be disturbed by waves or currents during the settling process, resulting in unsuccessful settlement. Recently, Bergström et al. (2003) showed that the attachment and early post-fertilization processes in Fucus are sensitive to high levels of nutrients. As concentrations of 5 to $25 \%$ of exudates of decaying Pilayella contained very high levels of nutrients (2.5 to $12.6 \mu \mathrm{mol} \mathrm{l}^{-1}$ phosphate, 0.9 to $4.7 \mu \mathrm{mol} \mathrm{l}^{-1}$ ammonia), observed negative impacts at these concentrations may be an effect of nutrient toxicity. However, the decline in germination and the reduction of rhizoid development at exudate concentrations of 5 to $25 \%$ were similar with exudates from both fresh and decaying Pilayella, despite nutrient levels being much less in the exudates from fresh Pilayella. The attachment at 6 and $12 \mathrm{~h}$ was also reduced in both treatment media at the lowest tested concentration $\left(0.1 \%,<0.1 \mu \mathrm{mol} \mathrm{l}^{-1}\right.$ phosphate, nitrate and ammonia), so this reduction was unrelated to nutrient levels. Therefore, nutrient level is not the factor causing the retarded attachment, and may only partly explain the adverse effects on germination and rhizoid development. The results imply that Pilayella contains substances other than nutrients that are toxic to or interfere with early life stages in Fucus.

A recent study has shown that 2 common green macroalgae (Ulva fenestrata and Ulvaria obscura) from the northeastern Pacific had similar toxic properties in reducing development of Fucus gardneri Silva zygotes and oyster larvae (Nelson et al. 2003). It was suggested 

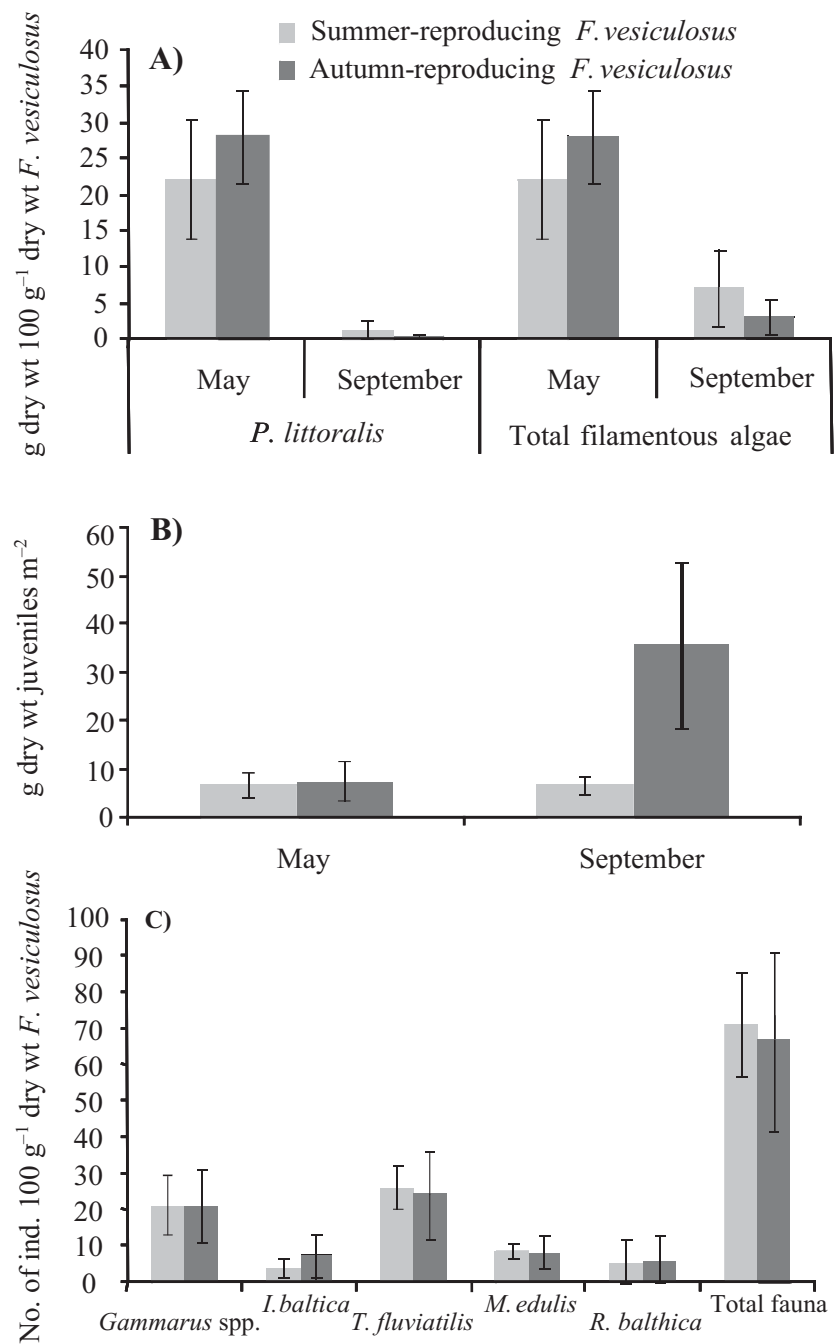

Fig. 3. (A) Biomass of epiphytic Pilayella littoralis and total filamentous algae ( $\mathrm{n}=3)$. (B) 1 to $2 \mathrm{yr}$ old juveniles of Fucus vesiculosus collected in 2 seasons (i.e. May and September) under the canopy of summer- respectively autumn-reproducing $F$. versiculosus $(\mathrm{n}=3$ for all variables except juveniles collected in September under the canopy of summer-reproducing $F$. vesiculosus which has $\mathrm{n}=4$ ). (C) Abundance of the 5 most common macrofaunal species and the total number of macrofauna in summer- and autumn-reproducing $F$. vesiculosus ( $\mathrm{n}=7$ for summer- and $\mathrm{n}=6$ for autumn-reproducing F. vesiculosus). The species are Gammarus spp., Idotea baltica, Theodoxus fluviatilis, Mytilus edulis and Radix balthica (formerly Lymnaea peregra). Bars show mean value $\pm \mathrm{SE}$

that the toxic impacts of blooms of these green algae might be more important than are generally recognized (Nelson et al. 2003). As Pilayella is one of the dominant algae in the Baltic Sea in summer (Wallentinus 1979, Kiirikki \& Lehvo 1997, Lotze et al. 1999), any toxic substance released by this species may have significant consequences in coastal zones. Toxic substances released by Pilayella may, for instance, contain polyphenolic substances known as phlorotannins known to be produced by brown algae, including Pilayella (Ragan \& Glombitza 1986). The negative effects we found of Pilayella exudates on the early life stages of Fucus, could be a consequence of these substances, which have been suggested as having allelopathic effects on unicellular (McLachlan \& Craige 1964, 1966) and crustose red algae (Fletcher 1975). Pilayella exudates may also contain organobromine compounds that are produced naturally by brown algae (Gschwend et al. 1985) for chemical defence and as hormones (Gribble 2000). These substances are easily released into the surrounding water (Gschwend et al. 1985). Since low concentrations of bromine inhibit germination and apical hair formation in Fucus (Andersson et al. 1992), it is also possible that organobromine compounds from Pilayella exudates are responsible for the negative effects shown in this study. The structure of phenols and the occurrence of brominated compounds in Pilayella are so far unknown, and research aimed at identifying these substances is needed.

The positive effect of high concentrations of exudates on Fucus survival may indicate a process of germling 'hardening' - i.e. the surviving germlings have become more resistant during exposure to adverse conditions (Chapman \& Fletcher 2002). It may also be reasonable to believe that the higher concentrations of exudates contained substances that stimulated surviving germlings. The survival rate in the control was low (around 25\%), and limiting nutrient levels in this treatment may explain this result. The higher nutrient levels in the Pilayella exudate treatments than in the control may, for example, have benefited growing germlings which survived the critical attachment and germination processes. The results also suggest and confirm that survival during the early life stages is a non-linear function of age (Brawley \& Johnson 1991), which emphasises the importance of including various life stages in toxicity tests and other ecologically relevant experiments.

\section{Physical impact}

Besides the chemical impact, Pilayella also, as hypothesised (H-4), substantially reduced Fucus recruitment by physical means if it was present on the substrate prior to settling of Fucus embryos. The inhibition of Fucus recruitment is likely to be a result of space pre-emption. This may explain the observed negative correlation between cover of filamentous algae and cover of Fucus in the Baltic Sea (Worm et al. 1999). Similar interference competition has been found to occur between Fucus and both the common green 
algae Cladophora glomerata (Berger et al. 2003) and Enteromorpha spp. (Worm et al. 2001).

\section{Field relevance and ecological consequences}

As hypothesised, the field studies revealed great differences in the biomass of epiphytic and epilithic Pilayella and total filamentous algae between the 2 different periods of Fucus reproduction, the highest biomasses occurring in May (H-5). The smaller amount of filamentous algae (especially Pilayella) in autumn may give zygotes from autumn-reproducing Fucus an advantage over zygotes from summer-reproducing Fucus. However, the biomass of 1 to 2 yr old juveniles did not differ between the summer- and autumnreproducing Fucus. Hence, the result did not support the hypothesis that the autumn-reproducing Fucus would have higher juvenile biomass than would the summer-reproducing Fucus (H-6). This result may be due to very high variation in juvenile biomass under the autumn-reproducing Fucus. Thus, a larger field study is required to determine the true differences in recruitment success between the summer- and autumn-reproducing Fucus.

The field studies further revealed that the biomass of epilithic Pilayella growing under the Fucus canopy in May (35 $\mathrm{g}$ dry wt $\mathrm{m}^{-2}$ ) was lower than implied by measurements made in similar areas without macroalgal canopy, where Pilayella may reach over $200 \mathrm{~g}$ dry wt $\mathrm{m}^{-2}$ (Wallentinus 1979, S. Råberg unpubl. data). Since our attachment experiment showed that the settling rate of Fucus zygotes was retarded in the presence of Pilayella exudates, zygotes in the field may easily be transported away from the area of Fucus canopy and hence be forced to compete with even higher abundances of epilithic Pilayella and filamentous algae in general. Besides physical competition and allelopathic interactions, filamentous turfs also tend to trap fine sediment and particles (Eriksson et al. 1998, Airoldi 2003 and references therein), further decreasing the possibility of Fucus recruits establishing themselves on suitable substrate. Based on the present results and other observed negative correlations between filamentous algae and Fucus (Worm et al. 2001, Berger et al. 2003), we predict that the likelihood of Fucus re-invading or colonizing habitats already dominated by a flora of annual filamentous algae are small. Such interference competition would be of minor importance in exposed areas, however, where the whiplash effect of adult Fucus prevents large-scale establishment of filamentous algae (Kiirikki 1996).

The higher biomass of Pilayella in summer indicates that the autumn-reproducing Fucus may encounter less competition with Pilayella for substrates and less nega- tive interactions with exudates, and therefore have a competitive advantage over summer-reproducing Fucus. According to the null hypothesis (H-7), there were no differences in the amount of epiphytic and epilithic Pilayella and total filamentous algae or abundance and biomass of associated macrofauna between summer- and autumn-reproducing Fucus. Therefore, a potential shift from a community dominated by summer-reproducing Fucus to a community dominated by autumn-reproducing Fucus would not change the overall species composition in the ecosystem.

Acknowledgements. We thank S. Nylin and the PhD students from the 'Writing scientific papers' course at the University of Stockholm, as well as 3 anonymous referees for their valuable comments, which have contributed to improving the manuscript. We also thank Stephan and C. Savage for reviewing the text. Research support was provided by the MARBIPP programme, the Swedish Environmental Protection Agency and the Stockholm Marine Research Centre.

\section{LITERATURE CITED}

Airoldi L (2003) The effects of sedimentation on rocky coast assemblages. Oceanogr Mar Biol Annu Rev 41:161-236

Andersson S, Kautsky L, Kautsky N (1992) Effects of salinity and bromine on zygotes and embryos of Fucus vesiculosus from the Baltic Sea. Mar Biol 114:661-665

Aneer G (1987) High natural mortality of Baltic herring (Clupea harengus) eggs caused by algal exudates? Mar Biol 94:163-169

Berger R, Malm T, Kautsky L (2001) Two reproductive strategies in Baltic Fucus vesiculosus L. Eur J Phycol 36:265-273

Berger R, Henriksson E, Kautsky L, Malm T (2003) Effects of filamentous algae and deposited matter on the survival of Fucus vesiculosus L. germlings in the Baltic Sea. Aquat Ecol 37:1-11

Berger R, Bergström L, Granéli E, Kautsky L (2004) How does eutrophication affect different life stages of Fucus vesiculosus in the Baltic Sea? - a conceptual model. Hydrobiologia 514:243-248

Bergström L, Berger R, Kautsky L (2003) Negative direct effects of nutrient enrichment on the establishment of Fucus vesiculosus in the Baltic Sea. Eur J Phycol 38:41-46

Brawley SH, Johnson LE (1991) Survival of fucoid embryos in the intertidal zone depends upon developmental stage and microhabitat. J Phycol 27:179-186

Brownlee C, Bouget FY (1998) Polarity determination in Fucus: from zygote to multicellular embryo. Sem Cell Dev Biol 9:179-185

Cederwall H, Elmgren R (1990) Biological effects of eutrophication in the Baltic Sea, particularly the coastal zone. Ambio 19:109-112

Chapman AS, Fletcher RL (2002) Differential effects of sediments on survival and growth of Fucus serratus embryos (Fucales, Phaeophyceae). J Phycol 38:894-903

Eriksson BK, Johansson G, Snoeijs P (1998) Long-term changes in the sublittoral zonation of brown algae in the southern Bothnian Sea. Eur J Phycol 33:241-249

Eriksson BK, Johansson G, Snoeijs P (2002) Long-term changes in the macroalgal vegetation of the inner Gullmar fjord, Swedish Skagerrak coast. J Phycol 38:284-296 
Fletcher R (1975) Heteroantagonism observed in mixed algal cultures. Nature 253:534-535

Gribble GW (2000) The natural production of organobromine compounds. Environ Sci Pollut Res 7:37-49

Gschwend PM, MacFarlane JK, Newman KA (1985) Volatile halogenated organic compounds released to seawater from temperate marine macroalgae. Science 227: 1033-1035

Haage P (1975) Quantitative investigations of the Baltic Fucus Belt macrofauna: 2. Quantitative seasonal fluctuations. Contributions from the Askö laboratory, No. 10, University of Stockholm, Stockholm

Hällfors G, Kangas P, Niemi $\AA$ (1984) Recent changes in the phytal at the southern coast of Finland. Ophelia Suppl 3: 51-59

Johansson G, Eriksson BK, Pedersén M, Snoeijs P (1998) Long-term changes of macroalgal vegetation in the Skagerrak area. Hydrobiologia 385:121-138

Kangas P, Autio H, Hällfors G, Luther H, Niemi Å, Salemaa H (1982) A general model of the decline of Fucus vesiculosus at Tvärminne, south coast of Finland in 1977-91. Acta Bot Fenn 188:1-27

Kautsky H (2000) Små förändringar i växternas djuputbredning. Small changes in depth extension. Miljötillståndet i egentliga Östersjön, Årsrapport 2000, Stockholm Marine Research Centre Annika Tidlund and Ulrika Brenner, Stockholm, p 62-63 (in Swedish with English figure legends)

Kautsky H, Kautsky L, Kautsky N, Kautsky U, Lindblad C (1992) Studies on the Fucus vesiculosus community in the Baltic Sea. Acta Phytogeogr Suec 78:33-48

Kautsky N, Kautsky H, Kautsky U, Waern M (1986) Decreased depth penetration of Fucus vesiculosus (L.) since the 1940's indicates eutrophication of the Baltic Sea. Mar Ecol Prog Ser 28:1-8

Kevekordes K (2001) Toxicity tests using developmental stages of Hormosira banksii (Phaeophyta) identify ammonium as a damaging component of secondary treated sewage effluent discharged into Bass Strait, Victoria, Australia. Mar Ecol Prog Ser 219:139-148

Kiirikki M (1996) Experimental evidence that Fucus vesiculosus (Phaeophyta) controls filamentous algae by means of the whiplash effect. Eur J Phycol 31:61-66

Kiirikki M, Lehvo A (1997) Life strategies of filamentous algae in the northern Baltic Proper. Sarsia 82:259-267

Kropf DL (1997) Induction of polarity in fucoid zygotes. Plant Cell 9:1011-1020

Lotze HK, Schramm W, Schories D, Worm B (1999) Control of macroalgal blooms at early developmental stages: Pilayella littoralis versus Enteromorpha spp. Oecologia 119: 46-54

McInnes AG, Ragan MA, Smith DG, Water JA (1984) Highmolecular-weight phloroglucinol-based tannins from brown algae: structural variants. Hydrobiologia 116/117: 597-602

McLachlan J, Craige JS (1964) Algal inhibition by yellow ultraviolet-absorbing substances from Fucus vesiculosus. Can J Bot 42:287-292

McLachlan J, Craige JS (1966) Antialgal activity of some simple phenols. J Phycol 2:133-135

Middelboe AL, Sand-Jensen K (2000) Long-term changes in macroalgal communities in a Danish estuary. Phycologia $39: 245-257$

Editorial responsibility: Otto Kinne (Editor-in-Chief), Oldendorf/Luhe, Germany
Naturvårdsverket (Swedish Environmental Protection Agency) (1999) Bedömningsgrunder för miljökvalitet. Kust och hav. Naturvårdsverket, Report 4914, Swedish Environmental Protection Agency, Stockholm (in Swedish)

Nelson TA, Lee DJ, Smith BC (2003) Are 'green tides' harmful algal blooms? Toxic properties of water-soluble extracts from two bloom-forming macroalgae, Ulva fenestrata and Ulvaria obscura (Ulvophyceae). J Phycol 39:874-879

Nilsson J, Engkvist R, Persson LE (2004) Long-term decline and recent recovery of Fucus populations along the rock shores of southeast Sweden, Baltic Sea. Aquat Ecol 38:587-598

Ragan MA, Glombitza KW (1986) Phlorotannins, brown algal polyphenols. In: Round FE, Chapman DJ (eds) Progress in phycological research, Vol 4. Biopress, Bristol, p 129-241

Rönnberg O, Mathiesen L (1998) Long-term changes in the marine macroalgae of Lågskär, Åland Sea (N Baltic). Nord J Bot 18:379-384

Rosenberg R, Cato I, Förlin L, Grip K, Rodhe J (1996) Marine environment quality assessment of the Skagerrak, Kattegat. J Sea Res 35:1-8

Schramm W (1999) Factors influencing seaweed responses to eutrophication: some results from EU project EUMAC. J Appl Phycol 11:69-78

Schramm W, Nienhuis PH (eds) (1996) Marine benthic vegetation - recent changes and the effects of eutrophication. Springer, Berlin

Serrão EA (1996) Reproductive ecology of Fucus vesiculosus Linnaeus in the Baltic Sea. PhD dissertation, University of Maine, Orono, ME

Serrão EA, Kautsky L, Brawley SH (1996) Distributional success of the marine seaweed Fucus vesiculosus L. in the brackish Baltic Sea correlates with osmotic capabilities of Baltic gametes. Oecologia 107:1-12

Vadas RL, Johnson S, Norton TA (1992) Recruitment and mortality of early post-settlement stages of benthic algae. Br Phycol J 27:331-351

Vahteri P, Mäkinen A, Salovius S, Vuorinen I (2000) Are drifting algal mats conquering the bottom of the Archipelago Sea, SW Finland? Ambio 29:338-343

Valderrama JC (1995) Methods of nutrient analyses. In: Hallegraeff GM, Andersson DM, Cembella AD (eds) Manual of harmful marine microalgae. IOC, Manuals and guides, No. 33 UNESCO, Paris, p 251-268

Vogt H, Schramm W (1991) Conspicuous decline of Fucus vesiculosus in Kiel Bay (Western Baltic): what are the causes? Mar Ecol Prog Ser 69:189-194

Wallentinus I (1979) Environmental influences on benthic macrovegetation in the Trosa-Askö area, Northern Baltic Proper. II. The ecology of macroalgae and submerged phanerogams. Contributions from the Askö laboratory, No. 25, University of Stockholm, Stockholm

Worm B, Chapman ARO (1996) Interference competition among two intertidal seaweeds: Chondrus crispus strongly affects survival of Fucus evanescens recruits. Mar Ecol Prog Ser 145:297-301

Worm B, Lotze HK, Boström C, Engkvist R, Labanauskas V, Sommer U (1999) Marine diversity shift linked to interactions among grazers, nutrients and propagule banks. Mar Ecol Prog Ser 185:309-314

Worm B, Lotze HK, Sommer U (2001) Algal propagule banks modify competition, consumer and resource control on Baltic rocky shores. Oecologia 128:281-293

Submitted: March 5, 2004; Accepted: October 10, 2004

Proofs received from author(s): March 8, 2005 